\title{
Social Mix Policies in Paris: Discourses, Policies and Social Effects
}

\author{
MARIE-HÉLÈNE BACQUÉ, YANKEL FIJALKOW, \\ LYDIE LAUNAY and STÉPHANIE VERMEERSCH
}

\begin{abstract}
Since the 1980s, the issue of social mix has become a public policy category in France. Enshrined in legislation, yet remaining controversial, it represents a major premise on which housing policies have been reconfigured. The concept of social mix is essentially based on who lives where, but it is also evoked in the context of urban renewal schemes for social housing estates, as well as in relation to new-build developments. A study of the bases of social mix policies conducted in Paris since 2001 in the context of the embourgeoisement of the capital shows the fundamental role of social housing stock. The City Council has become involved in policy decisions about both the location and the allocation of social housing. Particular attention has been paid to the middle classes in the name of the principle of 'balancing the population'. In order to measure the effects of the policy, this article relies on an analysis of two City of Paris schemes that have the stated intent of creating social mix. One of these schemes consists of redeveloping a working-class neighbourhood, Goutte d'Or, while the other involves the new acquisition of social housing in various more affluent neighbourhoods in the capital. This comparative study of the population shows that, whether in a neighbourhood poised for gentrification or in a more affluent neighbourhood, this policy has major effects on forms of local social cohesion, setting in motion individual trajectories and reshaping social and/or ethnic identities.
\end{abstract}

The issue of social mix has emerged as a strong dimension of public housing policies in highly differing urban and national contexts, to the point where, in texts produced by international institutions, it is presented as one of the criteria for sustainability; it has become a category of public policy. At the same time, it has been a recurring theme in political and academic debate since the turn of the twentieth century (Sarkissian, 1976). In 1961, Herbert Gans was already demonstrating its limits, on the basis of research into the new town of Levittown (Gans, 1961). A decade later, two French researchers, Jean-Claude Chamboredon and Madeleine Lemaire, came to similar conclusions in their research into the population of a large housing development in the Paris region (Chamboredon and Lemaire, 1970). In the contemporary context, where we are seeing an increase in social inequalities and, consequently, in forms of urban segmentation, social mix is put forward as a method and an objective for countering exclusion or ghettoization (Dansereau et al., 2002; Maurin, 2004). Its success parallels that of the "neighbourhood effects' thesis, which maintains that a concentration of poor households in certain areas

Translated from French by Karen George.

(c) 2010 The Authors. International Journal of Urban and Regional Research (c) 2010 Joint Editors and Blackwell Publishing Ltd. Published by Blackwell Publishing. 9600 Garsington Road, Oxford OX4 2DQ, UK and 350 Main St, Malden, MA 02148, USA 
produces disadvantageous social effects (Brooks-Gunn et al., 1993; Ellen and Turner, 1997; Atkinson and Kintrea, 2001; Cole and Goodchild, 2001; Musterd et al., 2003; Brännström, 2004) including social isolation (Wilson, 1996) or weak networks and declining social capital (Putnam, 1995). Although this thesis is far from proven (Briggs, 1998; Bramley and Karley, 2007), it nevertheless represents a major premise on which housing policies in France, the UK and the Netherlands have been reconfigured, redirecting residential construction subsidies into individual housing benefits and initiating housing demolition programmes or experimental housing mobility programmes (Briggs, 1997; Goetz, 2000; Bacqué and Sintomer, 2002; Goering and Feins, 2003; Tunstall, 2003). If in fact it is area-based poverty that poses the problem, dispersing poverty should provide a sufficient solution. This is the premise that we wish to discuss here, analysing the effects of these social mix policies on the basis of the Paris experience. For this we shall rely on an analysis of several schemes put into effect by the City of Paris with the stated intent of creating social mix. First we shall present their bases and modes of operation; then we shall go on to analyse their effects in terms of their impacts on population, the housing careers of inhabitants and in terms of social dynamics.

\section{Legislating social mix}

The distinctive feature of the French situation is the fact that this objective is enshrined in law - to the point where it has been made into a real political imperative. In order to understand the impact of this, we should look at some of the characteristics of the social housing stock in mainland France.

France has 4.5 million social housing units (17\% of the total housing stock), funded by state subsidies and loans and governed by rent controls. This statistic makes it average within Europe, falling halfway between the Netherlands (34\%) and Spain (5\%). With a private rental stock that is only slightly larger (20\%), and despite a significant proportion of owner-occupied housing (55\%), social housing plays a major role, since about $70 \%$ of French households are eligible for it on the basis of their incomes. It caters for the general public, aiming to include disadvantaged households but excluding those whose incomes are too high. This contrasts with both the residualist view that gives social housing a safety-net role on the Southern European model and the universalist perspective of general access (Ghekière, 2007). Nevertheless, the existence of categories of social housing to cover different income-based clienteles tends to segment this part of the housing stock and lead to specialization. However, it still has to meet two contradictory imperatives: on the one hand, to fulfil its social function by housing the most deprived people; and on the other hand, from a social mix point of view, to avoid poor households becoming concentrated in certain areas, creating predominantly poor populations.

The topic of social mix became a central one for municipalities and social landlords in France from the 1980s onwards. As the Dubedout Report (1983) shows, the quest for 'balance in the social composition of neighbourhoods' has been an explicit public policy objective since the early 1980s, though at that time its application was left to the judgement of local actors (landlords, municipalities). Since the 1990s, several laws have been passed on social mix and housing diversity, and these undoubtedly represent one of the specific features of the French context. In 1990, the Besson Act created the 'right to housing' and established an instrument to manage housing allocations that stressed access to social housing for the poorest households, while still emphasizing control over 'social equilibria'. In 1991, the Framework Act for Town Planning (Loi d'Orientation pour la Ville, or 'LOV') — initially dubbed 'the anti-ghetto law' — introduced 'the right to the city' and set an objective of $20 \%$ social housing for cities with populations over 200,000 , under pain of financial sanction. But even before it came into force, the penalty system had been repealed, leaving local authorities a great deal of freedom in applying the law. In 1998, the Social Exclusion Act (Loi relative à la Lutte contre les Exclusions) 
introduced a new social housing instrument - a social housing incentive loan (Prêt Locatif à Usage Social, or PLUS) that sought to 'promote social mix' at the scale of building tenure by combining different funding categories. A new stage was reached in 2000, within the framework of the Solidarity and Urban Renewal Act (Loi Solidarité et de Renouvellement Urbain, or SRU Act), which re-established the duty of every commune (with a population over 1,500 in the Île-de-France region and over 3,500 in other regions) to have at least $20 \%$ social housing, in order to offer a 'balanced distribution in the supply of accommodation'. Where communes 'in deficit' do not establish a catch-up programme in order to reach this $20 \%$, the Act provides for financial sanctions. Even though social mix is presented as a consensus issue in the political sphere, the heated protests that this provision drew from MPs on the Right reveal divergent views as to how it should be implemented.

In 2003, social mix was again at the heart of an urban redevelopment programme ${ }^{1}$ that proposed to 'provide neighbourhoods situated in sensitive urban areas (ZUS) with a structure that would allow sustainable development and the creation of social mix' - in other words, to demolish social housing estates in order to eliminate area-based poverty and to diversify the populations of these neighbourhoods, notably by building housing for the middle classes.

In France, therefore, although the concept of social mix is essentially based on who lives where, it is also evoked in the context of urban renewal schemes for social housing estates, as well as in relation to new-build developments. Although framed at the national level, the idea relies on local policies, giving municipalities the means to intervene in the construction and management of the social housing stock in partnership with social landlords. The scope for action that this gives local actors is all the more pronounced because the French social housing stock is relatively open to socially diverse groups.

\section{Paris: social housing as a tool for creating social mix}

From this point of view, the example of Paris is particularly interesting, since social mix is one of the major themes in the programme of the new City Council, headed by the Socialist mayor, Bertrand Delanoë, who was elected for the first time in 2001 after two decades in which the capital was managed by local politicians from the Right. The appropriation of this concept by the new council and its integration as the key element of housing policy demonstrate a strong desire to mark this administration as different from previous ones. Their objective is openly stated: by promoting social mix, they aim to 'tackle social and spatial inequalities in order to create a fairer Paris with a greater sense of solidarity'. ${ }^{2}$ Associated with notions of equality and social cohesion, the theme of social mix has again resurfaced in political debates, in an urban context marked by a very noticeable embourgeoisement of the capital since the late 1980s (Pinçon and PinçonCharlot, 2004; Préteceille, 2007). From that period onwards, the total number of people in routine and manual occupations has fallen steeply, while senior managers and independent professionals have gained ground. As can be seen in Figure 1, in the eastern neighbourhoods of Paris, the proportion of blue-collar workers to each manager fell between 1990 and 1999. In the 2000s, there has also been a considerable rise in property prices, with catch-up effects in working-class neighbourhoods that had previously been spared such increases (Figure 2). So, between 2000 and 2007, growth in prices of pre-war property, which was 54\% across the whole of Paris, reached over 59\% in the three main neighbourhoods of eastern Paris (the $18^{\text {th }}, 19^{\text {th }}$ and $20^{\text {th }}$ arrondissements).

1 In 2003, central government set a budget of $€ 14.5$ billion in order to start 60,000 new-builds, demolish 200,000 properties and rehabilitate 110,000 properties over a five-year period.

2 These are the terms used in a press release by the current mayor, Bertrand Delanoë, on the city's website: www.paris.fr 


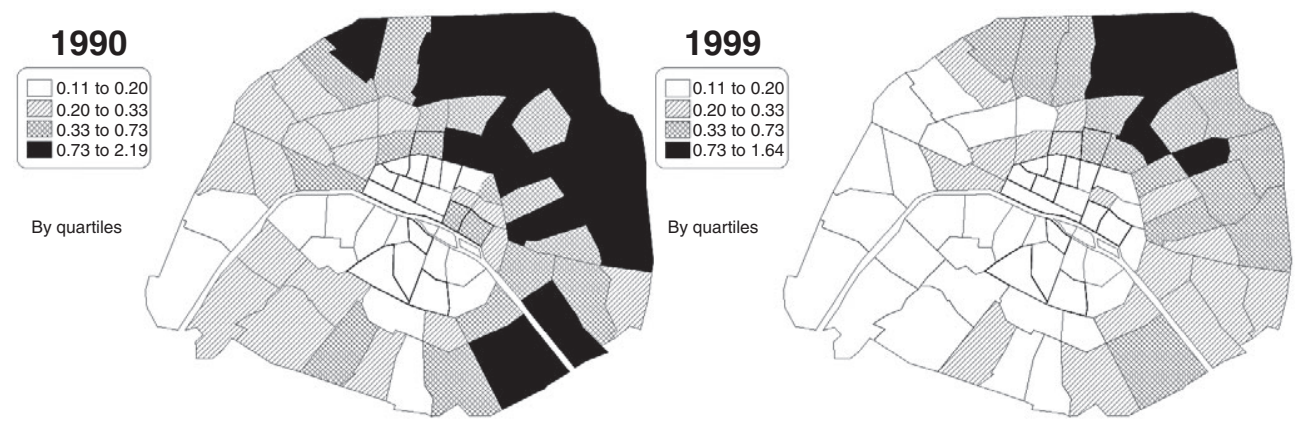

Figure 1 Manual workers per manager/independent professional (source: 1990 and 1999 censuses, INSEE)

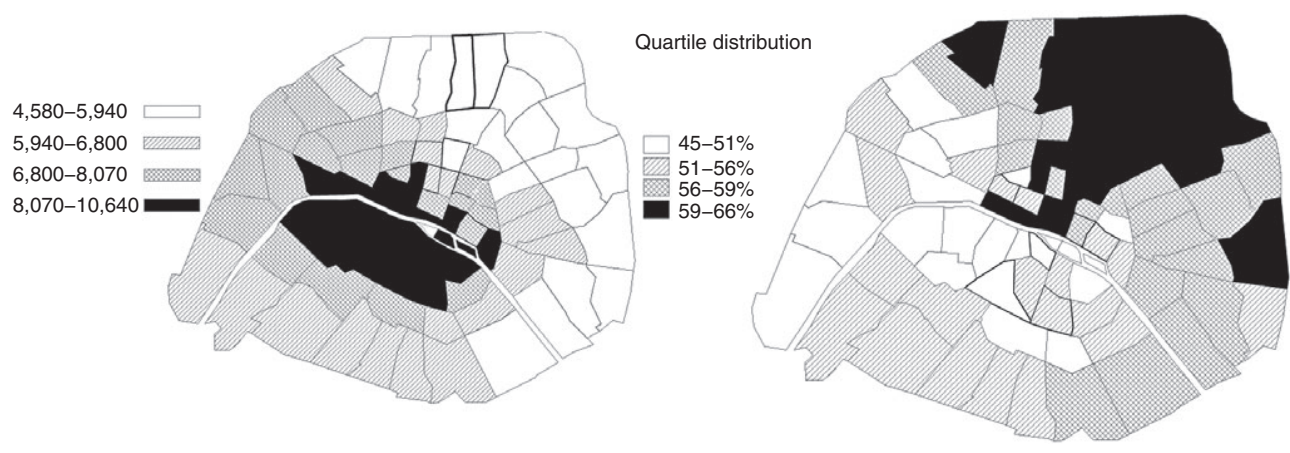

Figure 2 Property prices (in euros $/ \mathrm{m}^{2}$ ) 2007 and percentage price increases between 2000 and 2007 (source: Chamber of Notaries of the Paris Départements, 2007)

Selling prices had knock-on effects for private sector rent levels and contributed to low household mobility. Social housing appears to act as a refuge (with a very low turnover rate of 5\%), while the private rental stock, much of it pre-war, has seen a slight reduction, so that affordable housing has become more scarce and demand from poorly accommodated households has become tighter (over 100,000 are registered on social housing waiting lists).

Against this backdrop, the new City Council plans a 'sociological rebalancing' of the city, using low-cost rented housing - which in 2001 represented almost $13.4 \%$ of the Paris housing stock - as its principal tool. This strategy envisages both the construction of at least 4,000 housing units a year from now until 2020, which represents a higher proportion of social housing than is required by the SRU Act ( $25 \%$ instead of $20 \%),{ }^{3}$ and the geographical rebalancing of this housing stock, which is very unequally distributed between the west and the east of the city, ${ }^{4}$ in order to avoid the emergence of 'ghetto neighbourhoods'. In order to achieve this, the City Council has become involved not only in deciding the location of social housing, but also in allocations policy, so that it can

3 To this has been added a new provision (already in place in the UK), written into the local housing programme, which allows $25 \%$ of new property developments with more than $1,000 \mathrm{~m}^{2}$ of net habitable space to be given over to social housing in neighbourhoods that are 'in deficit' - that is, the more affluent arrondissements of central and western Paris.

4 In 2001, $43 \%$ of the social housing stock in Paris was located in the $18^{\text {th }}, 19^{\text {th }}$ and $20^{\text {th }}$ arrondissements, while the $7^{\text {th }}, 8^{\text {th }}$ and $16^{\text {th }}$ arrondissements together had only $1.2 \%$ (source: Paris City Hall, based on 1999 census). 
promote social mix, whether on the scale of the staircase, the building or the neighbourhood. So, in more affluent neighbourhoods of the capital, the City Council, in collaboration with social landlords, is creating social housing by buying existing buildings, some of which are already occupied by tenants; it allocates this housing to working-class households and to those who are considered key actors by virtue of their social position and/or their function in running the city: teachers, nurses and even refuse collectors (Launay, 2010). In working-class neighbourhoods, the City Council is pursuing the urban renovation policy that has been going on since the 1970s, constructing social housing to replace sub-standard buildings. To further its aim of creating social mix, it is also initiating intermediate rented social housing programmes, intended for those on middle incomes, and is developing new mixed housing schemes in order to restrict the spatial concentration of poor households and/or those of immigrant origin. This enables local politicians to promote settlement by more affluent households, which at the moment are in a minority in these neighbourhoods, but also to place part of the local population in the social housing stock in order to restrict any latent gentrification. Paris City Council is conscious of the impact that the gentrification process can have on poor households, some of which are of immigrant origin, and so it is mobilizing social housing in order to continue to guarantee a supply of affordable accommodation in these neighbourhoods.

Very particular attention has been paid to allocations policies, with a special place for the middle classes. This re-orientation towards the middle classes is explained by the public actors' desire to maintain them as a social category in Paris, so that in the long run the capital does not become 'a city just for people with the fattest wallets and people with the fattest subsidies'. ${ }^{5}$ The middle classes are viewed as guarantors of social cohesion by virtue of their function in 'balancing the population'. As they are the intermediate group linking the two extremes on the social ladder, their continued presence in Paris is presented as a central issue in the battle against the widely shared (though unconfirmed) diagnosis of growing social polarization. But they also represent a real issue at stake on the electoral front. On several occasions, they have mobilized against unit-by-unit sales schemes (where speculators have bought entire rental buildings and then sold them off apartment by apartment), demanding that the City Council intervene to protect them. In the last council election campaign, the Right-wing opposition proposed to offer them more firm support, in particular by promoting owner occupation. So there is consensus that the middle classes should be preserved in the name of social mix - of which they are supposed to be the pivot. ${ }^{6}$

This particular social mix policy therefore has a twofold objective: firstly, to eliminate pockets of poverty; and secondly to open up more affluent neighbourhoods by implementing policy directions that will populate them with the working classes and the middle classes. Just like other social mix policies undertaken in Europe and the US, it starts from the premise of a 'neighbourhood effect' that views any concentration of poor households as problematic and confers on the middle classes the role of providing a social framework for the working classes, allowing them increased social opportunities. But its originality certainly lies in the central role that it gives to low-cost rented housing as a social mix tool, bringing together several social categories in the same building, not only in the old working-class neighbourhoods but also in more affluent neighbourhoods.

5 The expression 'la ville des plus aisés et des plus aidés' was used by the deputy mayor in charge of housing, and was then taken up by the Right-wing candidate during her campaign for the 2008 council elections. She criticized the incumbent Socialist City Council's policy, saying that it had the indirect effect of excluding families and middle-class households from social housing, even though they too experienced housing difficulties in the capital.

6 The vagueness of the concept of 'the middle classes' - where the plural form is a clear indicator of heterogeneity - allows public actors to develop a very general discourse. All the same, the term encompasses households in very different situations, so these different political currents are not always appealing to the same 'middle classes'. 
Since its implementation, this policy has seen undoubted success in numerical terms, as the annual objective that the council set itself has been achieved (it has produced an average of 4,300 units). For all that, it remains marginal in relation to the Paris housing stock. However, the policy has met with heated criticism from opposition councillors and, in particular, from the mayors of the more affluent arrondissements. In the course of debates and demonstrations, its detractors have based their arguments on the supposedly inadequate lifestyles of social housing tenants compared to the way of life in upmarket neighbourhoods - for example, in terms of the retail offer. Secondly, they have denounced any policy exclusively favouring the working classes that would push the middle classes out of the social housing sector. Finally, the high cost of these schemes compared with other acquisitions in working-class neighbourhoods of Paris has also been controversial. But, for those promoting this policy, these drawbacks represent the price to be paid for creating social mix at the Paris scale: this inevitably requires special efforts to be made.

\section{Working-class neighbourhoods, bourgeois neighbourhoods: two social mix policies}

Our analysis focuses on two types of scheme, both reflecting City of Paris policy: firstly, the urban redevelopment of a working-class immigrant neighbourhood, Goutte d'Or, intended to bring in new households belonging to the middle classes; and secondly, schemes to acquire pre-war buildings in order to bring the working classes or the 'lower-middle classes' into upmarket neighbourhoods.'

The objective of social diversification in the Goutte d'Or neighbourhood has been on the agenda since the commitment was made to an urban renovation plan in the late 1970s. For a long time, the neighbourhood has primarily accommodated the working classes (49\% in 1982) and immigrants (34.8\% foreigners in 1982). Its housing stock consists mainly of small rented pre-war flats with no amenities (36\% without inside WC in 1982). This first plan aimed to demolish 1,400 housing units in the southern part of the neighbourhood, to build a new complex of 900 social housing units there and to encourage the rehabilitation of the private housing stock. Diversifying the population of the neighbourhood was an underlying issue from the start of the renovation/rehabilitation scheme: a 'sociological shift' ${ }^{8}$ was expected. Despite everything, diversification remains relatively low, because of pressure from community associations and because of operational difficulties that obliged the City Council and its Social Housing Office to rehouse a significant proportion of residents within the neighbourhood (Bacqué and Fijalkow, 2006). In the end, both the construction of social housing and the rehousing of families served to consolidate the social and ethnic population of the southern part of the neighbourhood, accentuating social differentiation in the area. The biggest changes affected the private housing stock. At the scale of the neighbourhood as a whole, the proportion of people in routine and manual occupations fell; trends in the proportions of the various socio-occupational categories between 1990 and 1999 demonstrate greater social diversification in the population. Although they are only half as much represented in Goutte d'Or as in Paris overall, the upper and upper-middle classes settled in greater numbers in 1999 than they did in 1990, notably on the western and eastern peripheries of the neighbourhood (Figure 3).

From 2001, the new City Council majority wanted more rapid social change and urban development in the neighbourhood: they opted to finance new housing programmes

7 So that our data and observations could be re-examined, we chose to retain the name of the neighbourhood that formed the subject of our research - Goutte d'Or, Paris 18. On the other hand, our respondents' data were processed in such a way as to respect their anonymity. Politicians and senior officials were identified by their roles.

8 Debate in session of Paris City Council, 19 September 1983. 


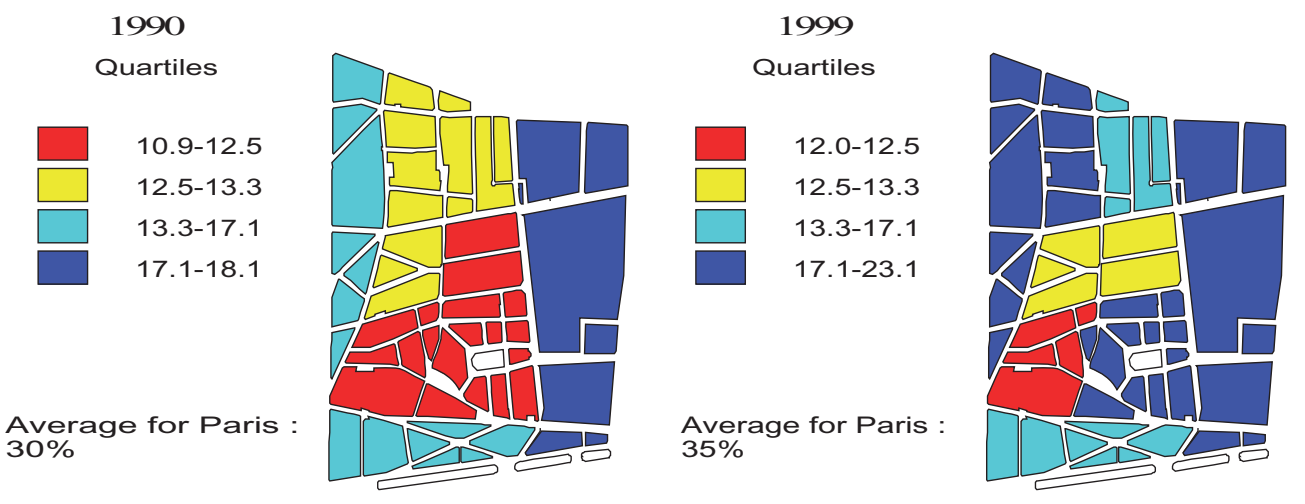

Figure 3 Percentage of people in higher managerial and professional occupations, 1990 and 1999 (source: 1990 and 1999 censuses, INSEE)

through a mix of various funding methods, and they targeted some programmes at the middle classes. The allocation of social housing was the focus of particular attention and of a special dispensation that allowed municipal councils in the arrondissements to reserve a third of social housing for middle-class households. In fact, the population has started to change anyway, as new households - tenants or owner-occupiers in the private sector - have come to settle in a neighbourhood with some of the lowest prices in Paris (against a backdrop of soaring property prices).

The Goutte d'Or material on which we shall be relying here is the result of preliminary research into the urban project, followed by four more targeted studies: a qualitative sociological analysis of new owner-occupiers in the private sector (Mandel, 2005); a study of four pre-war buildings (Florentin, 2007); a study of seven social housing properties delivered since 2000 (Sissoko, 2007); and an analysis of the social housing population resulting from the first phase of the scheme (Merlot, 2006). Within this framework, about 100 interviews were conducted with residents. In addition, community councils and various local participatory bodies were tracked and observed over a two-year period, and about 20 interviews were conducted with representatives of community groups and non-profit associations, as well as with other social actors.

Although the social mix policy within working-class neighbourhoods consists of attracting 'middling' households, in more affluent neighbourhoods the reverse is true there, in contrast, it consists of allowing the settlement of working-class households. So the second main line of the City Council's social mix policy is to change the populations of more affluent neighbourhoods. In order to provide these arrondissements with enough social housing to make up their 'deficits', ever since the inauguration of the new council administration, the deputy mayor in charge of housing has been seeking 'to grab any opportunities to acquire land or property'. ${ }^{9}$ From 2001 to 2007, an estimated 3,175 housing units, of which over two thirds were intended for lower-income households, were acquired or built in the central and western arrondissements of Paris, with the intent of creating social mix. ${ }^{10}$ Implementation of this new housing policy relies on an innovative instrument, the acquisition-conventionnement - a form of public-private partnership agreement that enables the municipality and social landlords to acquire partly occupied buildings and to designate them as subsidized social housing, with or

9 Expressed in these terms by a senior official from Paris City Hall during a 2007 interview.

10 Figures provided by Paris OPAC (the Public Development and Construction Office for Paris). This is a municipal public body which manages the City Council's social housing. 
Table 1 Social structure of four buildings acquired by Paris OPAC (\%)

\begin{tabular}{cccccc}
$\begin{array}{c}\text { Independent } \\
\text { Professionals and } \\
\text { Senior Managers }\end{array}$ & $\begin{array}{c}\text { People in Routine } \\
\text { and Manual } \\
\text { Occupations }\end{array}$ & $\begin{array}{c}\text { Jobless } \\
\text { People }\end{array}$ & $\begin{array}{c}\text { People with } \\
\text { Higher Education }\end{array}$ & $\begin{array}{c}\text { People with no } \\
\text { Further or Higher } \\
\text { Education }\end{array}$ \\
\hline A & 37 & 37 & 12 & 38 & 25 \\
\hline B & 17 & 67 & 17 & 50 & 33 \\
\hline C & 30 & 25 & 18 & 65 & 21 \\
\hline D & 44 & 18 & 19 & 54 & 32 \\
\hline
\end{tabular}

Source: 2006 sociological survey on population and housing, OPAC de la Ville de Paris

without improvement works. This new mechanism makes it easier to create social housing in arrondissements where tracts of land are rare and expensive. It also allows housing to be delivered quickly. ${ }^{11}$

Our research looked at four such schemes. The first (A), situated in the richest part of the $16^{\text {th }}$ arrondissement, is a typical nineteenth-century Parisian building containing 17 housing units, purchased empty by Paris OPAC (the Public Development and Construction Office for Paris). The second (B), in another part of the $16^{\text {th }}$ arrondissement, is a similar building containing 27 units, purchased by Paris OPAC partly occupied. Eleven units acquired social housing status when they were handed over in 2003, and the social landlord is waiting for the 'old' tenants to depart in order to allocate the remaining units to new households selected by the social housing allocations committee. The third (C) is another nineteenth-century Parisian building with 141 units, situated in the $9^{\text {th }}$ arrondissement, bought by OPAC from its private landlord in 2002 . The fourth (D), situated in the $15^{\text {th }}$ arrondissement, is of relatively recent (1970s) construction and consists of 181 prestige housing units with views over historic areas of the capital. During our survey in 2006, these different sites provided an illustration of a sociologically diversified population (see Table 1). We found a large proportion of people in higher managerial occupations, with a great deal of both economic and cultural capital, white-collar workers with much less educational capital and fewer financial resources, and finally jobless households whose main resources consisted of transfer incomes.

The material on which we are relying here consists of about 50 interviews conducted in these buildings, with both 'old' occupants, resident there since before the purchase, and new tenants, to whom this housing had recently been allocated. In addition to this qualitative corpus, we processed questionnaires completed by about three quarters of the tenants from the $9^{\text {th }}$ and $15^{\text {th }}$ arrondissement schemes, as well as statistical data obtained from the landlords' files.

This research, conducted within one working-class neighbourhood and several middle-class neighbourhoods, enabled us to assess the effects of the City Council's 'social mix' policy, in terms of the statistical rebalancing of populations and from the point of view of the social representations and dynamics involved in these changes. Far from arriving at the kind of binary evaluation (for or against social mix) that frequently

11 In addition to these acquisition-conventionnement schemes, in 2005 the City Council made use of a mechanism (that was limited in scope from a quantitative point of view and might rather be described as a surgical operation) whereby it reclassified over 500 intermediate housing units in more affluent neighbourhoods as PLA-I, PLUS and PLS social housing, in order to allocate them to lower-income households. PLA-I, PLUS and PLS are schemes that offer subsidized loans to local authorities, social or private landlords so that they can build, acquire or renovate properties for social housing use. 
results, we found that the City Council's policy has had very diverse effects, in both individual and collective terms. Its first direct consequence has been the fairly significant transformation of the local population.

\section{Who benefits from social mix policies?}

\section{Social housing for the working classes}

At first sight, a trend shared by more affluent neighbourhoods and working-class neighbourhoods is the shift of social housing to poor, working-class populations. Despite lower-middle-class households being rehoused in Goutte d'Or, the population there remains working class, and the large majority are lone-parent families of immigrant origin with few qualifications. In the $9^{\text {th }}$ and $15^{\text {th }}$ arrondissements, the average income of occupants of the buildings bought by OPAC has fallen markedly. A larger number of tenants left the $9^{\text {th }}$ arrondissement following the purchase, as the building there originally included more households belonging to the upper and upper-middle classes; but in the $15^{\text {th }}$ arrondissement this group - already in a minority - has disappeared completely. In Building $C$, the outgoing households had an average monthly income of $€ 3,695$ (€1,748 per capita household income), while those who have replaced them achieve only $€ 1,862$ (€555 per capita). This decline in the population's prosperity has been accompanied by an increase in its density, with the arrival of several families who have five, seven or even eight children. In both Building $C$ and Building D, about half the households that came in between 2006 and 2008 are poor (that is, they have a disposable monthly income situated around the poverty line, which for France is between €700 and $€ 800$ per capita); the other half are mostly working class, with the addition of a few from the lower-middle classes. ${ }^{12}$ Therefore, the City of Paris's social mix policy primarily benefits the poor and the working classes, whether of immigrant origin or not.

However, we must clarify three important points. The first is that, overall, the households that have entered the social housing stock through the schemes we studied may be described as stable: their incomes are low, but they are in permanent employment. In Buildings $\mathrm{C}$ and $\mathrm{D}$, it is rare to find people who are claiming welfare (revenu minimum d'insertion, or RMI, which provides a minimum income for those not entitled to unemployment benefit) on the basis that they have not worked for several years. There, residents' incomes are low, but they have incomes, although most of them are working part-time. There are very few extremely poor or long-term unemployed households. From this point of view, there is an observable difference between the population of the social housing that was created in Goutte d'Or in the 1980s and 1990s and the population of the recently acquired buildings.

The second clarification relates to the differences between households entering social housing in the $16^{\text {th }}$ arrondissement and those in the other neighbourhoods. In the $16^{\text {th }}$ arrondissement, social housing allocations seem to have met a need to maintain a certain prestige: reflecting the apprehensions of the local population, there are very few people from the 'most working-class' categories, and the large majority of beneficiaries are

12 For the purposes of this research, we divided the populations of the buildings into three major categories:

- the working classes: people in routine and manual occupations

- the middle and lower-middle classes: people in intermediate occupations (intermediate socio-occupational categories)

- the upper and upper-middle classes: people in higher managerial and professional occupations This categorization, which we created by looking at how salaries and occupations intersected, as well as at spheres of activity, presupposes the existence both of elites and of 'the poor'; it reflects our desire to introduce nuances in place of a single 'middle class' category that would flatten things out too much. It is not intended to be universal, or generalized to other situations. 
white-collar workers. There are very few blue-collar workers, and those there are have partners who are white-collar workers; there are very few immigrants, and these are well educated: social housing in upmarket neighbourhoods must be in tune with the arrondissement. This 'harmony' is facilitated by prioritizing the geographical recruitment of new tenants, with social housing being granted to applicants from the arrondissement, who are supposed to be 'better adapted' to the neighbourhood (Launay, 2006). Similarly, in the $9^{\text {th }}$ arrondissement, the Social Housing Office currently keeps an eye on how the population of Building $\mathrm{C}$ is 'working', admitting that it allocates housing to 'known' families who will not pose any problems. Fewer precautions are taken with the buildings in Goutte d'Or, a neighbourhood where there is a much larger majority of working-class people than in the $9^{\text {th }}$ arrondissement. Thus, the City of Paris allocations policy is not consistent across all neighbourhoods; it takes into account the areas within which the programmes are being put into effect. Social housing can cover differing situations, therefore; but equally, it is embedded in a local property market.

\section{In working-class neighbourhoods, there are indirect effects for the middle and upper classes}

Finally, as the Goutte d'Or neighbourhood clearly illustrates, it seems to be necessary to distinguish between direct beneficiaries of housing allocations (the poor and the working classes, as we have just highlighted) and indirect beneficiaries - the upper and uppermiddle classes (people in higher managerial and professional occupations), who profit from the general increase in the value of the housing stock and, more broadly, of the local space. The City Council's housing policy has to be considered within the framework of neighbourhood renovation, which also affects the private rental housing stock, since this type of redevelopment involves both rebuilding and rehabilitation, which means tha t between $43 \%$ and $62 \%$ of housing units (depending on the sector) have not been replaced - mainly those which accommodated the most deprived people. Thus, a survey of several private buildings shows that works instigated by managing agents put the most economically vulnerable households in a difficult position, in some cases leading them to leave the neighbourhood and often to leave Paris (Mandel, 2005). So allocations, demolitions and improvements converge to eliminate pockets of poverty, to the detriment of the most impoverished households.

In Goutte d'Or, the City Council's social mix policy and its built environment policy have been carried forward into its policy on shops and services, with the establishment of a design quarter and the building of a multimedia library, and even into the planning and management of green spaces and the rehabilitation of public gardens. Since 2004, a debate about moving the "ethnic market' ${ }^{13}$ has been on the agenda of the community councils. The upper-middle classes are party to these decisions, putting pressure on the City Council to speed up the development of the neighbourhood into a place that harmonizes more closely with their interests and lifestyle. The survey of 52 households living in the pre-war buildings, of whom about 20 are owner-occupiers, shows the recent settlement of people in higher professional occupations (teachers, researchers, journalists), often with no children, who have taken up the theme of a balanced social mix and present themselves as guaranteeing the smooth running of the neighbourhood and implementing the changes it needs, legitimizing their presence through their social role: 'to bring the neighbourhood up, people like us had to come and settle here'. Some of them have formed community pressure groups demanding the 'return' of law and order: one of these groups has even christened itself 'Right to Peace and Quiet'.

Property transactions reveal how these developments in the neighbourhood have changed the housing stock (Bougras, 2008): between 2002 and 2005, a third of buyers were managers and independent professionals and a quarter were in intermediate

13 The Goutte d'Or neighbourhood accommodates a lot of 'ethnic' or 'exotic' goods traders, mainly African. This means it attracts customers from all over the Île-de-France region. 
Table 2 Cross-tabulated socio-occupational categories of purchasers and vendors (\%)

\begin{tabular}{lccccr} 
Vendors & $\begin{array}{c}\text { Managers, } \\
\text { Independent } \\
\text { Professionals }\end{array}$ & $\begin{array}{c}\text { Intermediate } \\
\text { Occupations }\end{array}$ & $\begin{array}{c}\text { Routine } \\
\text { White-Collar } \\
\text { Occupations }\end{array}$ & $\begin{array}{c}\text { Routine Manual } \\
\text { Occupations }\end{array}$ & Total \\
\hline $\begin{array}{l}\text { Purchasers } \\
\begin{array}{l}\text { Managers, independent } \\
\text { professionals }\end{array}\end{array}$ & 47.67 & 42.78 & 36.97 & 31.25 & 43.12 \\
\hline $\begin{array}{l}\text { Intermediate } \\
\text { occupations }\end{array}$ & 35.27 & 42.22 & 30.25 & 50.00 & 37.18 \\
\hline $\begin{array}{l}\text { Routine white-collar } \\
\text { occupations }\end{array}$ & 14.34 & 13.33 & 24.37 & 15.63 & 16.13 \\
\hline $\begin{array}{l}\text { Routine manual } \\
\text { occupations }\end{array}$ & 2.71 & 1.67 & 8.40 & 3.13 & 3.57 \\
\hline \begin{tabular}{l} 
Total \\
\hline
\end{tabular} & 100.00 & 100.00 & 100.00 & 100.00 & 100.00 \\
\hline
\end{tabular}

Source: Statistics for 589 sales of vacant pre-war housing units, 2000-06 (Bougras, 2008)

occupations; these proportions grew over the period, to the detriment of people in routine and manual occupations (Table 2). The latter sold their properties to managers and independent professionals, while, in contrast, managers and professionals sold above all to people like themselves.

In Paris, the City Council's initial objectives seem to have been partly achieved, in that these schemes have clearly contributed to social diversification in these buildings. However, the filter of geographically based allocations in the more affluent neighbourhoods, the preference given to stable households over the poorest sections of the community, and even the way that indirect beneficiaries - that is, the upper and upper-middle classes - have been taken into account all lead to a more nuanced picture of the effects of City Council policy, even more so since the ties between different social groups within the neighbourhoods have also been called into question.

\section{Setting housing trajectories in motion}

A social mix policy has much broader consequences than merely that of re-adjusting the social balance. With the arrival of population categories that have previously been under-represented or unrepresented, the housing trajectories of all the residents of a given building or neighbourhood are reshaped, and this in turn reshapes their representations of the neighbourhood. Any assessment of a new housing deal must depend on repositioning it within the whole trajectory of which it forms an intrinsic part: for incoming occupants, the degree to which they represent their arrival positively or negatively is correlated to the position of this housing on their residential path, as well as to the amount of freedom that they have been able to assert in choosing this move. For existing occupants, some re-evaluation of their position comes into play even though they have not moved.

For some occupants, the presence on their building of a plaque showing that the property belongs to a social landlord is an irredeemable marker of the loss of its symbolic value. This was the case for a lot of inhabitants of the more affluent neighbourhoods that we studied, in particular the occupants of Buildings D and C, who perceived the fact that they were living in 'council housing' ${ }^{14}$ as a form of downward social mobility, even though nothing in their housing position had changed. 'There we were, in a lovely,

14 In everyday French, 'HLM' (Habitation à Loyer Modéré, or low-cost rental housing) has become synonymous with social housing, and has some of the same connotations as the term 'council housing' in the UK. 
spacious old apartment, we had really got on in life, had some success - you might even say we had made it, and then ... they tell us that we're living in social housing; we feel as if we left our friends and family, we came to Paris just to be given a hard time'. ${ }^{15}$ When place of residence signals social success through its architectural quality or the status of the other occupants, the loss of one of these qualities creates a corresponding experience of failure, whether it involves the arrival of 'lower' social classes or a deterioration in the upkeep of shared spaces (the latter commonly attributed to OPAC management failures). This sense of in situ downward social mobility may trigger actual changes in housing trajectories, leading families to move away. The meaning ascribed to these departures is rarely uniform. It depends on earlier pathways and on value systems: for some, it entails becoming an owner-occupier, though of a smaller property, while others find they can live somewhere bigger 'but in the suburbs'. The latter choice is most often viewed negatively by social categories with an attachment to living near the centre of Paris. This is also the reason why some households remain in place even though they have a feeling of being held captive, attributable at least as much to their financial limitations as to the restrictions they themselves place on their scope for possible action.

Conversely, one of the particular features of social mix schemes in more affluent neighbourhoods is that they represent an opportunity for upward social mobility for working-class households. Moving into an upmarket neighbourhood is a lucky break in the eyes of many, especially for their children, since it brings them into contact with 'the right kind of people' and gives them access to 'better' schools. In addition, the setting for these schemes is provided by prestige buildings, and the fact that their social housing status can remain invisible is particularly appreciated: 'it doesn't look like council housing'. Most of the time, the occupants who declare themselves satisfied are those for whom moving into this housing is a step onto the housing ladder, if not a step up. The external décor provides evidence of their 'success', evidence that is all the more important for those whose social status is shaky. 'It's a block of luxury flats, very well maintained, so from that point of view we were very agreeably surprised, because by comparison with other council flats ... in fact, we feel we are very privileged in that regard... for the most part, social housing is situated on the outskirts, and the architecture is not nearly as nice as this block, you can really see that this wasn't originally built as social housing'. ${ }^{16}$

So 'new' and 'old' households live side by side in the same building, and are dependent on one another for their social status, at least in the way the occupants experience and adapt to this status. Apart from the forms of passive downward social mobility or active upward social mobility that we have just mentioned, we should also note cases of active downward social mobility, when moving into social housing represented a setback on a pathway otherwise situated in the upper echelons of society. Mrs Fabian, ${ }^{17}$ who had recently become a tenant of one of the schemes in the $16^{\text {th }}$ arrondissement, was forced to leave her previous housing following her husband's disabling illness; she said: 'My husband had got too used to living on the boulevard Suchet; here it just doesn't have the same prestige - perhaps it's a better location, but it doesn't have the same prestige. It was very well-to-do there - the rent was twice as much ... Now, it's as if we are people with social problems'. Apart from the fall in prestige, which she experienced as almost pathologically painful, the new neighbours whom this housing imposed on her represented too strong a marker of her sliding down the social scale to be easily tolerated: 'I'm not a snob, but I'm just not used to this kind of population; the people who live here are the kind of people who live in social housing'.

15 Mrs Maquard, aged 45, married, two children, upper/upper-middle class, moved into the building in 1988.

$16 \mathrm{Mr}$ Bel, aged 27, cohabiting, IT specialist in his first job after qualifying, recently moved into the building. He had grown up in working-class neighbourhoods in the Paris region.

17 Mrs Fabian, aged 77, upper/upper-middle class, forced to apply for social housing following financial problems linked to her husband's illness, moved into the building in 2004. 
Finally, for some of the households, it was not a question of social mobility in either direction, but of normalization and of achieving housing stability, notably in Goutte d'Or, where the tradition of accommodating the most disadvantaged people continues. For many households in this neighbourhood, access to social housing — apart from bringing them standard amenities - represents both the end of long experience of rental insecurity and a social guarantee. As renovation/rehabilitation schemes go forward, they lead the poorest people, notably those without secure contracts of employment (who are not strongly represented in City of Paris housing allocations), to quit the neighbourhoods concerned. Our survey was not able to put any figures on this 'evaporation', but it creates another dynamic in housing: departures, probably to working-class neighbourhoods in the suburbs and into private sector housing - which thus play a part in displacing and repositioning area-based poverty within the Paris region. ${ }^{18}$ However, some people choose to make themselves heard through protest, like those who have formed the Coordination des Mal-Logés (Coordinating Committee for Badly Housed People) in the $18^{\text {th }}$ arrondissement; this informal grassroots group fights poor housing conditions and insecurity, not only through protest actions but also through day-to-day community solidarity.

The difficulty of assessing the consequences of a social mix policy can be read in the range of movements that it opens up in trajectories, even where there is sometimes no change of residence, as well as in the diversity of representations that it entails. Talking about the same place, new tenants on an upward trajectory were ready to maintain that 'it's marble everywhere, everywhere just shines', whereas an old tenant pointed out that 'the metal doors are all slashed', 'the garden is in a state, it's the first year I've seen it like this, it's dreadful'. Discourses on social mix and its consequences and, more broadly, assessments of the human and architectural environment of social mix schemes must be heard and understood in the context of the trajectories of the people putting them forward and of the impact of such schemes on these trajectories. This is all the more true because social relations within the building are not themselves exempt from alteration under the effect of population arrivals and departures.

\section{What are the social dynamics?}

Whether in a neighbourhood poised for gentrification or in a more affluent neighbourhood, municipal policy has effects on forms of local social cohesion. The nature of social relations depends to a large extent on the threat that each group represents for the social positions and housing trajectories of the others (Bacqué et al., 2010). Housing allocations and acquisition-conventionnement schemes, in significantly altering the social composition of buildings and neighbourhoods, act on the state of opposing forces.

However, ignorance is the most common currency between social groups which intersect and live side by side in neighbourhoods and buildings without ever meeting. There are certain kinds of behaviour that run through the stairwells of Goutte d'Or: the hurried ignorance of highly qualified tenants, for whom the neighbourhood is just a place to pass through on their upward social and housing trajectory; the polite mutual avoidance of working-class families, whether from immigrant backgrounds or not, in a situation where avoiding one's neighbour means avoiding the social fate that one is desperately trying to escape (Schwartz, 1990). It is behaviour far-removed from the idealized image of unshakeable working-class solidarity in the face of social vulnerability.

18 Christine Lelèvrier's research into the renovation of the social housing stock in the Paris region produced the same type of results; renovation is to the advantage of households with relatively more resources, and it leads to greater vulnerability for the poorest (Lelévrier, 2005). 
One of the most common — though still ambiguous — forms of cross-class solidarity links the middle classes who are the heirs of the 'new class' (Gouldner, 1979) with the working classes. This is because, through their value system, people working in the arts, healthcare, the social services and even education, who have more cultural than economic capital, are inclined to value and develop links with the working classes. So they form relations that might be described as demonstrating solidarity, while still stressing the frameworking and educational dimension. In Goutte d'Or, they also have a great deal of involvement in community-based associations for managing the neighbourhood. Similarly, within Buildings $C$ and D, although both the recent nature of the OPAC purchases and the more privileged profile of the tenants have not allowed such practices to develop, the middle classes nevertheless show social goodwill that predisposes them to play what is for some a 'peacemaking' game and for others means bringing new social housing tenants 'back into normal life'.

More common are configurations that promote internal solidarities within each social group: in Goutte d'Or, for example, these bring together recently arrived owneroccupiers belonging to the upper-middle classes, who are in a hurry to see the neighbourhood develop in order to validate their investment in land and the pragmatic decision they have made to gamble on an imminent increase in values. The slow pace of change encourages them to form alliances and get organized in order to set about forms of social conquest, making use of fairly strong attempts at social control and to gain power on the local political scene (Bacqué and Fijalkow, 2006). Here, solidarity has certain strong similarities to the kind of mutuality that used to prevail in a lot of buildings affected by social mix policies. 'They [the new tenants who have difficulties] don't bother me in my day-to-day life, but it's rather a pity, because we no longer have the familiarity that we used to share here'. ${ }^{19}$ This solidarity took similar substance among the upper and upper-middle classes in buildings in the $16^{\text {th }}$ arrondissement when they were disturbed by the arrivals of social housing tenants after the buildings moved into public management (Pinçon and Pinçon-Charlot, 1989). It is all the more pronounced when length of residence matches social status, whether it involves the old tenants of buildings purchased by OPAC in the 15th arrondissement, or new OPAC tenants in Building A in the $16^{\text {th }}$ arrondissement.

The third dimension of social relations linked to the City Council's social mix policy lies in the tensions that it generates or increases. So, even before they moved into the upmarket neighbourhoods, OPAC tenants had to face acrimony - 'we have enough problems here already, with all the traffic' — and suspicion - 'we just hope that they won't steal a lot' - notably on the part of shopkeepers, whom they then decided to boycott. Moreover, these social mix schemes have sometimes come up against resistance on the part of existing tenants, notably in the form of community-based associations. So, all the old tenants in the housing units in Building $\mathrm{C}$ got together to obtain information on the way the scheme to purchase and rehabilitate their building would proceed, and OPAC now recognizes that this scheme did not go forward in the best conditions of diplomacy and transparency. Their ways of going about things have helped to confirm the idea that 'OPAC is looking to make us leave', which predominates among the old tenants, and this has contributed to a deterioration in the extremely tense relations between the landlord and these residents.

This form of resistance springs less from rejection of social mix as such — 'obviously this isn't a case of being against a social mix' - than from disquiet about its consequences, triggering the passive mobility process that we have already considered. The more 'worrying' the composition of the population vis-à-vis the housing trajectories and social positions of the existing tenants, the stronger these forms of resistance are going to be. From this point of view, one source of new tensions - for example, in the schemes in the $9^{\text {th }}$ and $16^{\text {th }}$ arrondissements - is linked to the arrival of households of African origin, which up to then had not formed part of the population of these buildings.

19 Mrs Millet, aged 55, married, upper/upper-middle class, moved into Building C in 2000. 
The City of Paris has rehoused some households from cheap residential hotels where fatal fires occurred in 2005. In both schemes, our analysis of social representations produced by residents highlights the existence of a system whereby residents classify other residents into two groups, explicitly defined in racial terms: on the one hand, 'us', the French, 'white people'; and on the other hand, 'them', 'sub-Saharan Africans, North Africans'. Thus, one occupant of a building in the $15^{\text {th }}$ arrondissement $t^{20}$ talked about a 'bi-ethnic', 'French-African' building. Here the racial dimension is at the heart of representations of social mix and operates as a key criterion in the system of classification and downgrading constructed by the residents. ${ }^{21}$ Although social mix has its own dynamic and its own imagined world, here this largely coincides with the racial dimension. It arises when existing tenants distance themselves from 'Others', who are figures of insecurity, in order to defend a position that the new social status of the building has begun to threaten. So these new tenants, whose cultural differences from the dominant native culture are emphasized, provide a focus for any difficulties and are made responsible for them by a mechanism that has already been clearly identified (Dench et al., 2006). However, there seem to be fewer real tensions than are stated in the discourses, though the place occupied by this ethnic dimension of social relations does emphasize all the difficulties involved in these new experiences of living together. On their side, households of African origin do not necessarily appear to be satisfied with these allocations either, when - among other things - in the $16^{\text {th }}$ arrondissement they cannot find any shops in the vicinity that are of any use to them. Therefore, in a certain number of cases, they have applied to move away again. The racial dimension is also present in Goutte d'Or, often euphemized. New inhabitants primarily describe the neighbourhood through its ethnic diversity; when they are asked about the notion of social mix or are discussing the City Council's social mix policies for the area, most of the time it is the racial dimension that they comment on first. Similarly, several of them indicated to us that they had withdrawn a child from school because she or he was 'the only white kid in the class'.

Finally, another social distance has been established: members of the lower-middle class group who have been allocated social housing dread mixing with the working classes, in particular in the neighbourhood's state schools, which they carefully skirt around. Goutte d'Or is also symptomatic of tensions linked to social mix, when members of the upper-middle classes join forces against any forms of neighbourhood investment or branding that hamper its increase in value, from the most classic (the ethnic shops) to the most deviant (drug users). In any case, in their intermediate position, the middle classes run the risk of tensions from all sides, with members of the working classes potentially dragging them down - 'it's as if we are people with social problems' and members of the higher social groups likely to unseat them from their dominant position - 'now there's a risk of gentrification'. These tensions are sometimes expressed even in the street and the public space, when new inhabitants of Goutte d'Or are treated as strangers to the neighbourhood, when new shops are vandalized or when shopkeepers in the $16^{\text {th }}$ arrondissement treat social housing tenants with obvious disdain.

\section{Conclusion}

Analysing the social effects of Paris City Council's 'social mix' policy allows us to look more broadly at the bases of this idea, which has met with success despite a certain conceptual vagueness. Although the rhetoric of social mix in public policy arenas,

$20 \mathrm{Mr}$ Sabin, aged 65, cohabiting, upper/upper-middle class but on a downward trajectory, moved into the building in 1969 .

21 However, beyond these discourses, this dimension is difficult for researchers to grasp: there is no OPAC data that enables us to quantify the number of 'black' households. But although this racial criterion rests on a social construction, it nonetheless plays a part in constructing social reality (Fassin and Fassin, 2006). 
dressed up in the ideal of urban harmony and the right to the city, seems highly consensual nowadays (not only in France, but also elsewhere in Europe and in the US), the results are uneven to say the least. If public policy is to produce effects, it is not enough to 'cloak' it in virtuous slogans.

In the various schemes that we studied, the objectives of eliminating the poorest concentrations of population and of keeping the working classes and the middle classes in the capital seem to have been fulfilled in the short term, even though it must be accepted that these results remain very marginal at the scale of the whole Paris housing stock. However, it appears that the most excluded populations do not benefit from these policies - although they suffer from them when, in urban redevelopment projects like the one in Goutte d'Or, they no longer have the means to remain in the neighbourhood and can hardly make themselves heard in the public space. The pursuit of the objective of social mix relies on the desire to push the problem - that is, poor households - a bit further away, without worrying about the devastating effects on these families, who do not have access to the social housing created in the more affluent neighbourhoods. While the main argument for social mix principally evokes the rejection of social and spatial exclusion in the name of the interests of poor populations, in the final analysis it is the 'middle classes' who are at the centre of concerns, and the most vulnerable people are actually losers in the social change and urban development undertaken.

The rhetoric of social mix tends to make the middle classes the reference point for the 'social bond', imposing their cultural and social norms within a logic of 'integration' where the working classes remain confined in a situation of domination. The social dynamics created in this way include a strong dimension of conflict between the 'old' and the 'new', connected as much with living alongside people one has not chosen, with feelings of downward social mobility and with forms of social and racial rejection, as with the opposition between different social norms. So, for the working classes, the eagerly awaited social cohesion and the school effects of the spatial proximity of the middle classes have not materialized. In fact, at various scales, these social mix policies seem to create as many problems as they solve.

Policies claiming to guarantee 'the' social mix do not have homogeneous social effects. Social effects differ according to the housing trajectories of the households actively or passively affected by the policies and according to local social and urban characteristics. Some households benefit from these social mix experiments, which allow them to move up a step on the housing and social ladders and to enter an urban environment previously inaccessible to them. But we must take seriously the combined effects of the increasingly insecure status of wage-earners and the segmentation of space within cities, which have created situations where certain neighbourhoods primarily accommodate certain types of people, some neighbourhoods become poorer, and the built environment of these housing estates declines, often taking living conditions with it. Moreover, the embourgeoisement of Paris - a phenomenon in many major cities and pressure on the property market are very real, and they serve to accentuate the gaps between rich and poor areas of the capital. So can social mix legitimately be something more than the promotion of a choice offered to individuals by institutions and those who direct them? Social mix cannot settle the issue of poverty through social dispersion; this can be done only through vital social redistribution.

Marie-Hélène Bacqué (mhbacque@club-internet.fr), Mosaïques, Université de Paris Ouest Nanterre La Défense, UMR LAVUE, 200 Avenue de la République, 92001 Nanterre,

France, Yankel Fijalkow (yankel.fijalkow@gmail.com), Centre de Recherche sur I'Habitat, Ecole d'Architecture Paris Val de Seine, UMR LAVUE, 15 Quai Panhard Levassor, Paris 75013, France, Lydie Launay (launay.lydie@yahoo.fr), Mosaïques, Université de Paris Ouest Nanterre La Défense, UMR LAVUE, 200 Avenue de la République, 92001 Nanterre, France and Stéphanie Vermeersch (stephanie.vermeersch@paris-valdeseine.archi.fr), Centre de Recherche sur I'Habitat, Ecole d'Architecture Paris Val de Seine, UMR LAVUE, 15 Quai Panhard Levassor, Paris 75013, France. 


\section{References}

Atkinson, R. and K. Kintrea (2001)

Disentangling area effects: evidence from deprived and non-deprived neighborhoods. Urban Studies 38.12, 2277-98.

Bacqué, M.-H. and Y. Sintomer (2002) Peut-on encore parler de quartiers populaires? Espaces et Sociétés 108-9, 29-47.

Bacqué, M.-H. and Y. Fijalkow (2006) En attendant la gentrification: discours et politiques à la Goutte d'Or (1982-2000). Sociétés Contemporaines 63, 63-83.

Bacqué, M.-H., Y. Fijalkow, A. Flamand and S. Vermeersch (2010) Comment nous sommes devenus HLM, les opérations de mixité sociale à Paris dans les années 2000. Espaces et Sociétés 140-41, 76-93.

Bougras, M. (2008) Les ventes immobilières à la Goutte d'Or 2000-2005. Master's dissertation in Geography, University of Paris 7.

Bramley, G. and N.K. Karley (2007) Homeownership, poverty and educational achievement: school effects as neighbourhood effects. Housing Studies 22.5, 693-721.

Brännström, L. (2004) Poor places, poor prospects? Counterfactual models of neighbourhood effects on social exclusion in Stockholm, Sweden. Urban Studies 41.13, 2515-37.

Briggs de Souza, X. (1997) Moving up versus moving out: neighbourhood effects in housing mobility programs. Housing Policy Debate 8.1, 195-233.

Briggs de Souza, X. (1998) Brown kids in white suburbs: housing mobility and the many faces of social capital. Housing Policy Debate 9.1, 177-221.

Brooks-Gunn, J., G.J. Duncan, P.K. Klebanov and N. Sealand (1993) Do neighborhoods influence child and adolescent development? The American Journal of Sociology 99.2, 353-95.

Chamboredon, J.-C. and M. Lemaire (1970) Proximité spatiale et distance sociale. Revue Française de Sociologie 11, 3-33.

Cole, I. and B. Goodchild (2001) Social balance and mixed neighbourhoods in Britain since 1979: a review of discourse and practice in social housing. Society and Space 19, 103-21.

Dansereau, F., S. Charbonneau, R. Morin, A. Revillard, D. Rose and A.M. Seguin (2002) La mixité en habitation. INRS, Montréal.
Dench, G., K. Gavron and M. Young (2006) The new East End: kinship, race and conflict. Profile Books, London.

Dubedout, H. (1983) Ensemble, refaire la ville. La Documentation Française, Paris.

Ellen, I.G. and M.A. Turner (1997) Does neighborhood matter? Assessing recent evidence. Housing Policy Debate 8.4, 833-66.

Fassin, D. and E. Fassin (eds.) (2006) De la question sociale à la question raciale? Représenter la société française. La Découverte, Paris.

Florentin, D. (2007) La Goutte d'Or au gré des rues. Evolution du parc privé et analyse des mutations du quartier. Master's dissertation in Sociology, University of Paris 1 La Sorbonne.

Gans, H. (1961) The balanced community: homogeneity or heterogeneity in residential areas? Journal of the American Institute of Planners 27.3, 176-84.

Ghekière, L. (2007) Le développement du logement social dans l'Union européenne. Dexia Editions, Bruxelles.

Goering, J. and J. Feins (2003) Choosing a better life? Evaluating the Moving to Opportunity social experiment. The Urban Institute Press, Washington, DC.

Goetz, E.G. (2000) The politics of poverty deconcentration and housing demolition. Journal of Urban Affairs 22.2, 157-75.

Gouldner, A.W. (1979) The future of intellectuals and the rise of the new class. The Seabury Press, New York.

Launay, L. (2006) Mixité sociale et politique locale de l'habitat, quels effets sur les pratiques sociales des habitants? Master's dissertation in Sociology, University of Evry Val d'Essonne.

Launay, L. (2010) De Paris à Londres, le défi de la mixité sociale par 'les acteurs clés'. Espaces et Sociétés 140/41, 111-26.

Lelévrier, C. (2005) Rénovation urbaine, relogement et recompositions territoriales. Recherche Sociale 176, 24-41.

Mandel, C. (2005) Evolution du peuplement du parc privé et impact de l'opération de rénovation urbaine sur les stratégies résidentielles: enquête sur les nouveaux propriétaires de la Goutte d'Or. Master's dissertation, University of Evry Val d'Essonne.

Maurin, E. (2004) Le ghetto français: enquête sur le séparatisme social. Seuil, Paris. 
Merlot, E. (2006) Les effets sociaux de la politique de rénovation urbaine de la Goutte d'Or. Master's dissertation, University of Evry Val d'Essonne.

Musterd, S., W. Ostendorf and S. De Vos (2003) Neighbourhood effects and social mobility: a longitudinal analysis. Housing Studies 18.6, 877-92.

Pinçon, M. and M. Pinçon-Charlot (1989) Dans les beaux quartiers. L'épreuve des faits, Editions du Seuil, Paris.

Pinçon, M. and M. Pinçon-Charlot (2004) Sociologie de Paris. Repères Collection, Editions la Découverte, Paris.

Préteceille, E. (2007) Is gentrification a useful paradigm to analyse social changes in the Paris metropolis? Environment and Planning A 39.1, 10-31.

Putnam, R.D. (1995) Bowling alone: America's declining social capital. The Journal of Democracy 6.1, 65-78.
Sarkissian, W. (1976) The idea of social mix in town planning: an historical review. Urban Studies 13.3, 231-46.

Schwartz, O. (1990) Le monde privé des ouvriers. Hommes et femmes du Nord. PUF, Paris.

Sissoko, B. (2007) La mixité dans le parc social de la Goutte d'Or. Master's dissertation in Sociology, University of Evry Val d'Essonne.

Tunstall, R. (2003) 'Mixed tenure' policy in the UK: privatization, pluralism, or euphemism? Housing, Theory and Society 20.3, 153-9.

Wilson, W.J. (1996) When work disappears: the world of the new urban poor. Random House, New York.

\section{Résumé}

Depuis les années 1980, la notion de mixité sociale est devenue, en France, une catégorie de l'action publique. Légiférée, bien que discutée, cette notion représente un postulat majeur des reconfigurations des politiques du logement. Cette notion essentiellement fondée sur le plan résidentiel, est aussi bien évoquée dans le cadre des opérations de renouvellement urbain des ensembles d'habitat social que dans des opérations de construction neuves. L'étude des fondements des politiques de mixité, menées à Paris depuis 2001, dans le contexte d'embourgeoisement de la capitale, montre le rôle fondamental du parc de logement social. La municipalité intervient tant sur sa localisation que sur la politique d'attribution. Une attention toute particulière est accordée aux couches moyennes au nom du principe de l'équilibre de peuplement'. Pour mesurer les effets de cette politique, cet article s'appuie sur 'analyse de deux opérations conduites par la ville de Paris au nom de la mixité sociale. L'une de ces opérations consiste en la rénovation d'un quartier populaire, La Goutte d'Or, l'autre en la nouvelle acquisition de logements sociaux dans des quartiers aisés de la Capitale. L'étude comparée du peuplement montre, qu'il s'agisse d'un quartier en attente de gentrification ou d'un quartier aisé, les effets importants de cette politique sur les formes de cohésion sociale locale, induisant une mise en mouvement des trajectoires individuelles et une recomposition des identités sociales et/ou ethniques. 